\title{
Building a Negotiation Mechanism in EFL Classroom in Chinese Context: Concepts and Strategies
}

\author{
Shiyong Jiang ${ }^{1}$ \\ ${ }^{1}$ School of Foreign Languages, Leshan Normal University, Leshan, China \\ Correspondence: Shiyong Jiang, School of Foreign Languages, Leshan Normal University, 778\#, Binhe Road, \\ Shizhong district, Leshan, Sichuan Province, China. Tel: 86-136-7960-6220. E-mail: jsy2002@126.com; \\ 45856479@qq.com
}

Received: August 11, 2016

Accepted: October 5, 2016 Online Published: October 7, 2016

doi: 10.5539/elt.v9n11p29

URL: http://dx.doi.org/10.5539/elt.v9n11p29

\begin{abstract}
Foreign language teaching is a bilateral process in which both the teacher and students must play their roles effectively. However, lack of interaction is the problem many EFL teachers in China face. To make the teaching more effective, negotiation in the classroom becomes a must. This paper, based on the current situation of English teaching in China, probes into negotiation mechanism in EFL classroom and provides suggestions on how to apply negotiation mechanism in EFL classroom in China.
\end{abstract}

Keywords: negotiation mechanism, EFL classroom, Chinese context, concepts, strategies

\section{Introduction}

In the long history of foreign language teaching in China, the teacher works as the center of the class during the whole teaching process, organizing the class, presenting and clarifying language points with the expectation that students learn obediently and memorize facts accordingly. Obviously, students' initiatives and creativity were ignored within such a framework. Although it is admitted that interaction is the key to success of foreign language learning, it's still hard to find some effective ways to ensure successful interaction in Chinese context. How to know the students' expectation? How to realize a balance between the teacher and students? A common core in answering these questions lies in the effective interaction. Therefore, the quality of interaction in EFL classroom in China has become the most urgent issue for English language teaching. Currently, the problem is that too much is focused on the form of interaction while the nature of it is ignored. As a result, the effectiveness of interaction can not be ensured. Therefore, it is necessary to treat students as the equal social beings like the teacher. Students also have a role in the decision-making of teaching. Therefore, a harmonious negotiation mechanism between the teacher and students must be built in Chinese context.

Negotiation per se is not a new concept in language teaching; however, it has been ignored for years due to the understanding of language teaching in China. In fact, practices of negotiation were made in some countries and places in EFL/ESL teaching and were justified to be a success (Michael \& Andrew, 2002; Margaret, 2002). Nowadays, although some papers have been published on the new ideas like flipped learning and teaching, task-based language teaching, etc, seldom did teachers notice the factor of ecological balance of interaction. These new ideas of teaching as mentioned are of course attractive, yet the effectiveness is mainly determined by the quality of interaction in the classroom, which, on the contrary, has not been emphasized so far. Therefore, it is urgent to build an efficient negotiation mechanism in the classroom so that students will all be involved in the activities of teaching and learning, forming effective interaction accordingly.

\section{Understanding Negotiation in EFL Classroom}

\subsection{The Concept of EFL Classroom Negotiation}

Negotiation in the classroom can be considered as the reflection of sociocultural concepts of modern education. Typically, the teacher and students get together for the purpose of acquiring knowledge or developing abilities. However, in addition to their physical (or virtual) location and pedagogic function, classrooms are also social environments of communication. In the classroom, with language learning as the center, there are other factors affecting teaching and learning, such as learning environment, teaching methods, teaching style, learning paces and so on. To deal with these factors effectively, there must be certain negotiation between the teacher and 
students to incorporate the voices of both parties.

Generally, negotiation originates from the interactive movement of daily conversation and is a kind of social activity (Michael \& Andrew, 2002). Negotiation in the classroom mainly deals with the interactive relationship between students and the teacher. In other words, negotiation is utilized to make meaning clear and teaching and learning effective. Specifically, when people use their language to express whether they understand or not understand the speakers' intention, negotiation is thus established. As the manifestation of humanistic education philosophy, classroom negotiation concerns more of students' personality, affection, initiatives, individuality, etc., regarding them as independent persons. It is thus a process of empowerment and a way of developing learner responsibility (McCarthy, 1991). In a negotiable class, teaching and learning will be more interactive and democratic with both the teacher and students involved and matched successfully. Because of negotiation between the two parties, teachers are able to get the information of learning timely and adjust their teaching accordingly. What's more, students could have more opportunities to express their needs and requirements and learn more positively. Currently, this is especially true in a flipped classroom because students will have more freedom at their disposal and become more responsible for their own learning.

\subsection{Three Levels of Negotiation in EFL Classroom}

In an EFL classroom, negotiation involves the teacher, students and the reality of the environment of teaching and learning which form certain intricate and integrated ecological relationships in classroom. According to some researches, negotiation in the classroom can be divided into three dimensions, namely: Personal negotiation, Interactive negotiation, and Procedural negotiation (Michael, P. B. \&L., Andrew, 2002). The three levels of negotiation are not separated ones; rather, they are closely related and intermingled and function as a useful mechanism in classroom teaching and learning.

\subsubsection{Personal Negotiation}

Personal negotiation is a kind of psychological process which includes personal reflection and retrospection of learning factors like discrimination, analysis, synthesis, memory and reflection, etc. For instance, when people try to understand or interpret the knowledge they read or heard, negotiation is drawn between the possible meaning and the interpreted meaning. For instance, in an EFL class, when the student attempts to understand what "pinch" means in the context "David pinched himself to make sure it was true", he or she is actually having the personal negotiation mainly within his own thinking framework. He or she will ask questions like "What is the relation between "pinched" and the following part?" and "How to get the specific meaning in the phrase?" and son on. In this sense, negotiation refers to the process of the movement of complex personal mentality which cannot be observed directly.

\subsubsection{Interactive Negotiation}

Interactive negotiation originates from the nature of conversation primarily. When people express whether they understand or not other people's meaning, there would be interactive negotiation. Learning is produced in the process of negotiation, in which learners will be involved in the interactive negotiation. Interactive negotiation is the pivot of language acquisition (Long, 1981). During the process, the input needs to be clarified and therefore one who produces output of the target language should repeat, simplify and interpret the information so as to let it become the location of the creativity. In fact, interactivity is the common strategy in society in class which is used by the teacher and students consciously or unconsciously in and after class. If some students in the class ask the teacher what he means by saying "The old gentleman is pretentious", there would be the interactive negotiation of meaning between the teacher and students if the teacher clarifies it by saying that pretentious indicates "think too proud of himself".

\subsubsection{Procedural negotiation}

Procedural negotiation is mainly about how the class should be taught. Its primary function is to organize teaching successfully. During this process, some of the main decisions are of special attention, for example, who cooperates with whom? by what means? with what material? for what purpose? The teacher must make suitable decisions based on the answers to each of these questions through negotiation with students, and adjust the organization of teaching dynamically and flexibly. To make the teaching a success, the effectiveness of interaction between the teacher and students becomes crucial. Considering the organization of an EFL class, procedural negotiation thus has a more important role amongst the three dimensions, because it is responsible for the overall design of the classroom teaching, perfects the teaching plan, causes interactive negotiation, personal negotiation and prescribes the range and quality of the two. The three levels of negotiation can appear respectively or at the same time and can include each other. 


\subsection{The Effectiveness of Negotiation in EFL Classroom}

\subsubsection{Helping Teachers Make a Better Decision}

As a complex system, classroom teaching in its nature is always dynamic and unpredictable, and the teacher must make adjustment consistently in teaching and make decision according to the specific change (Jack \& Charles, 2000). To a certain degree, the quality of teaching effectiveness is determined by the quality of decision-making in the classroom. In the traditional teaching pattern in China, it is the teacher that makes decisions based on his/her own personal experience and understanding, and therefore subjectivity or randomness is something that can't be avoided. Although the wish might be good, the result is always out of expectation. Then, through negotiation, the teacher could get to know more of students' learning conditions, learning difficulties, etc. timely, which might be much more helpful for the teacher to penetrate into the learner's innate world of learning. As one important side of classroom negotiation, students surly have the right to take part in the process of decision-making, making the teacher's decision much more objective and inclusive. It's easy to find that if the two sides can meet in teaching and learning practice, the decision-making process as a whole would undoubtedly be bettered to a large extent.

\subsubsection{Promoting Interactivity in the Classroom}

Interactivity is one of the characteristics of modern foreign language classroom. As what many teachers believe, the quality of interactivity has great effect on teaching quality. In effect, negotiation forms the groundwork of interactivity since it may arouse students' activeness and initiatives in the classroom work. It is even safe to assert that a class without negotiation or minds meeting is somewhat superficial in terms of mutual understanding and adjustment. Building a negotiable classroom can make the teacher and students get closed to each other or match each other's understanding continuously. Besides, it can bridge the gap of authority and obedience between the teacher and students psychologically and affectively so as to bring the democratic atmosphere and high efficiency of classroom interaction. Then the power is not completely under the control of teacher, students could also be encouraged and empowered to participate in the teaching and learning process, to negotiate with teacher and to make decision of learning and teaching activities and tasks consequently. Through consistent negotiation and communication between the two parties, the whole process of teaching could become clearer and students will be more aware of self responsibility and autonomy of learning the language; besides, the teacher can also get timely feedback of his or her teaching.

\subsubsection{Prompting Students' Autonomy of Learning}

Autonomy of learning is a matter focused on by many researchers and practioners in recent years following the realization of student-centeredness reform in China's education. To make sure that teaching and learning of English as a foreign language is matched, it is necessary to find ways to stimulate students and promote their autonomy in learning. In a post-modernism era, students should be more responsible for their own learning and become more self-dependent inside and outside the classroom. Nowadays, the trend of flipped teaching requires students' autonomy badly which is closely related to effective negotiation in the classroom. For flipped teaching, negotiation functions as a basic instrument in creating learning opportunities and ensuring learning effectiveness.

Through negotiation under the control and guidance of the teacher, students can effectively participate in classroom decision making and build up their learning motivation, interest and driving force. In a negotiable classroom, students can have the right to negotiate with the teacher for the issues which were used to be the teacher's job in, such as making teaching aims, choosing learning methods and selecting evaluation model, etc. If they are entitled the right to express their ideas, and if they can be negotiated for their own learning, they will surely become more responsible for their own learning. As a result, autonomy of learning can be established; in the meantime, their potentiality and creativity will also be stimulated continuously towards the planned purposes as expected.

\section{The call for Negotiation Mechanism in Current Chinese EFL Classroom}

\subsection{EFL Teaching Requires a Good Environment of Interaction}

Foreign language teaching must be implemented in certain environment. Doctor Stern (1999) has pointed out that foreign language teaching context involves the society, school, situation and students and focuses more on the classroom interaction. In fact, these can be categorized into three dimensions, namely, the teacher, teaching process and students which consist of the unity of teaching. At present, although certain teaching targets are decided by the curriculum, syllable, the specific arrangement of teaching is still determined by the teacher in the classroom (Zhu, 2001). To ensure a better result, language teaching must be in accordance with the laws and principles of foreign language learning and teaching, especially be set in a good environment of interaction. In 
doing so, mechanism like negotiation between the teacher and students must be established to ensure the integration of the internal and external factors in EFL classroom. In such a case, to make sure that the teaching is students-centered, effective negotiation at different levels must be carried out for the mutual understanding and better interactivity between the teacher and students.

\subsection{EFL Classroom Must Be Bilateral}

Obviously, to some extent, the traditional model of EFL teaching as in middle school in China is unilateral since students' initiatives and motivation can't be aroused as expected. One apparent consequence of the current model of EFL teaching in China is that students loose their voices and remain passive "test machine" (Gao, 2013). Consequently, their potentiality of learning the target language is far from developed due to the lack of initiatives and motivation, and the classroom is normally dominated by the teacher. Therefore, in order to make EFL teaching a bilateral cooperation, it is urgent to emphasize students' important role in the teaching process, especially when the teacher and students have different ideas for the same issue. In so doing, interactive or procedure negotiation in classroom becomes more and more urgent, which will undoubtedly help to make the classroom more interactive and democratic. Amongst all the techniques in teaching and learning, negotiation might be the most important at present which will for sure promote students' initiatives, autonomy and self responsibility in learning.

\subsection{EFL Teaching Must Be in Line with the Development of Modern Education}

Traditionally, many EFL teachers in China argue that the final aim of language teaching is students' commend of the target language knowledge and skills. Within such a philosophy, language teaching is mainly test-focused and mechanical training-based. However, in recent years, in English language teaching, there has been a growing interest in providing students with opportunities to add their voices and perspectives to their own education in some countries (Cook-Sather, 2006; Cook-Sather \& Youens, 2007). The implication of it is that effective negotiation and democracy must be ensured in language classroom in China. Besides, modern education stresses on cooperation and democracy of learning, and in an EFL classroom students must not be passive accepters but active facts-discovers and explorers of learning and practice. In such a sense, it is essential that the teacher and students negotiate with each other in the classroom activities for a better learning result.

\section{The Strategies of Building a Negotiation Mechanism in Chinese Context}

To build the mechanism of negotiation in EFL classroom, there must be some aspects to be considered seriously. The teacher should first of all have such a concept of carrying out negation in classroom, understand the essence of negotiation and have some flexible strategies at his or her disposal. With both the theory and practice of English teaching considered, the teacher can have at least the following strategies:

\subsection{Form the Concept of Negotiation in Language Teaching}

Philosophically, concepts or ideas of the teacher determine teaching effectiveness in the first place. Although flipped teaching and learning are now in its blossom in China at present, many EFL teachers still haven't fully realized the important role of students and how to play their role effectively in the teaching activities. Classroom teaching in fact is an active process in which both the teacher and students must cooperate with each other, and the teacher must change the idea of how teaching should be and how students can function in the language classroom. In other words, EFL teachers should try to overcome the baffles of the traditional Chinese culture which set what to do and how to do in the classroom unilaterally by the teacher. With such understanding, it is better to bear in mind that more negotiation is required between the teacher and students in Chinese context. Consequently, the view of how to organize the class must in the first place be changed accordingly. The teacher's role is not only to teach, but also to help students engage in classroom decision-making through negotiation and to make it more suitable and scientific.

In the framework of building a negotiation mechanism, the teacher's role must be changed in the first place, from being the controller and knowledge passer to be the negotiator, the guide, the assistant of learning. In doing so, teachers' agency becomes essential. The so called agency is integral to teachers' capacity to reflect on and take action in their practice (Charteris \& Smardon, 2015). It is easy to find that the interactive negotiable model is beneficial for both the teacher and students in that not only the communication but also the feedback is timely and negotiable. All is considered, an EFL teacher must think about the questions like "what do students expect?", "How to support students by adjusting the teaching?" rather than teach the class merely based on their own personal experiences unilaterally. Thus, the teacher can have a better understanding of his or her students timely by interactive or procedure negotiation in the teaching practices. Surely, with the idea of negation in mind, the decision-making of class teaching will become much more scientific and objective as a result. 


\subsection{Realize Negotiation at the Three Levels Flexibly}

Negotiation in the classroom environment could be applied in accordance with the three levels of negotiation as what have been discussed above. Generally, foreign language teachers ought to work as the pivot to sponsor negotiation in the three dimensions since many students in China are somewhat passive. He or she must first make it clear of what to teach, how to teach and how the situation can be evaluated objectively. Also, the teacher should work the negotiation items out for students in class about what and how to do.

Practically, negotiation should be carried out on the basis of the three levels as what have been discussed. At the first level (personal negotiation), the individual student must be led by the teacher to negotiate with himself or herself about the learning methods, learning process, learning strategies, learning affect, learning anxiety, and so on. Questions like "Am I right to deal with the homework?" "Should I be more open in speaking in class?" should be asked with caution. In this sense, students are also allowed to turn to their peers or to the teacher for help whenever they feel necessary. Thus they could get answers through negotiation by themselves or the peers. In this process, students are supposed to adjust to the utmost to adapt to teacher's teaching in whatever aspects that might be possible. In other words, students should be critically reflective of their own learning situation in order to be in charge of their cognitive progress. This includes awareness, monitoring and self-regulation, and such meta-cognitive skills (Rowe, 1988). In this step, the teacher is responsible to help students make the feasible question or criterion so as to retrospect or reflect the learning process by themselves in all the possible dimensions concerned in language leaning.

Based on personal negotiation, at the second and the third level, namely, interactive and procedural negotiation, the teacher and students need to cooperate with each other for a better result of teaching and learning at the same time. At the two levels, negotiation functions even more important than personal negotiation because they concern more of the implementation of teaching. They exist in both content and procedure. Things like the teaching content, teaching pace, learning difficulties, learning and teaching style, learners' psychology, etc. should be discussed and negotiated timely so that both parties could acquire useful information of teaching or learning and the necessary feedback. As a result, the teaching process can become more transparent and easy to adjust and control.

The situation that decision-making is largely dominated by the teacher as it used to be in China will have to be changed, that is, more freedom ought to be allocated to students so that they can participate in the negotiation of decision-making on their learning, such as teaching content, teaching pace, learning strategies, the design of communicative task, the choice of teaching media and so on. Here, procedural negotiation is thus involved. Teachers should penetrate in the state of the mentality of students in order to know them in all aspects of their psychology, their motivation and attitudes in learning the language. The three levels discussed are not to be separated; rather, they are closely related to each other in a variety of channels. To apply negotiation into teaching and learning practice and to make it more effective, it is necessary to make a good arrangement of time for negotiation, which plays an important role in the whole framework of negotiation mechanism. One stage of negotiation is in the classroom teaching in which the teacher and students negotiate with each other for the simultaneous matter. However, a more systematic negotiation is throughout the whole teaching process, that is, both the teacher and students can give a review of their actions in learning and teaching, and then they can see it more clearly and negotiate with one another for a better solution.

\subsection{Decide the Dimensions of Negotiation in the Practice}

\subsubsection{Negotiate the Teaching Contents}

One of the most important dimensions of negotiation is the teaching contents. In a democratic classroom, it is sure that teaching content shouldn't and cannot be decided only by the teacher himself or herself following the fixed syllabus or curriculum, which was already set. In such a process, many facets of teaching contents must be considered very carefully. In China, the national curriculum determines the course and other materials like textbook, reference book, while the specific content in teaching is determined by the teacher. Different form the traditional teaching model of EFL in China, in a negotiated classroom, in terms of personal negotiation, students will have more power and freedom in deciding the teaching contents, such as the order of presenting the material, the adjustment of the material, which in turn will prompt their own initials in learning. For example, students themselves can first decide if they can accept the contents. Then it is important that through interactive negotiation the teacher get to know more of the nature of foreign language learning through negotiation with students. If students are still weak in understanding the content, it's the teacher's responsibility to make some changes of the teaching according to students' cognition. Meanwhile, the teacher should also know how to choose the appropriate examples in the classroom to adapt to students' learning condition. One example is that in 
the choice of teaching content of "allophones", many students feel puzzled at the concept. Through interactive negotiation, the teacher quickly understands this and chooses more simple examples like $[\mathrm{p}]$ and $\left[\mathrm{p}^{\mathrm{h}}\right]$ to let students experience the difference. As expected, they understand it clearly with the timely adjustment. To sum up, in order to make the teaching more effective, both teacher and students should cooperate positively and actively to determine the optimistic content of teaching under the concept of negotiation.

\subsubsection{Negotiate the Teaching Process}

Based on the teaching purpose and teaching content set through effective negotiation, EFL teachers should focus more on the process of teaching and learning in the classroom. It is much better to bear in mind that the manipulation of teaching and learning is flexible and that all the factors concerning learning must be considered seriously so as to make a fluent process. Generally, it is the teacher's responsibility to listen to students' voice and negotiate with them for whatever that might have influence on learning effect, such as learners' emotion, psychology, the non-intellectual factors, their mental operation characters, etc. The classroom must not be an institution that is always controlled by the teacher. The teacher should listen to students' voices to understand their learning purpose, motivation, requirements and how they expect teaching to be carried out, and regard students as the equal beings in the classroom ecological system. In the teaching process, there are a number of things need to be negotiated at the three levels of negotiation. For instance, the teaching methods, teaching model, teaching pace all need delicate change and adjustment so as to adapt to students' needs and conditions. Then, knowledge of such information through certain negotiation becomes essential.

Before teaching, there would be the presupposed teaching design and expectations for students. Usually, it is the teacher that chooses examples of learning and designs activities of learning based on his/her experiences. However, those presupposed examples or activities may not be suitable or not be appreciated by students as they also have their own expectations and understanding. Then certain adjustment based on the effective negotiation in class becomes essential. In the process of teaching, the teacher must reflect on his or her own teaching style, arrangement of time, and the differences and similarities between English and Chinese. Based on that, whenever there would be problems or baffles of learning the language, changes can be made immediately. In such case, group discussion, pair work, performance, games and so on could be adopted according to the necessity and the situation of the present classroom atmosphere and the teaching objectives. To make the negotiation more effective, the teacher must be responsible for the observation of students' learning and adjust the teaching pace accordingly. For example, an EFL teacher in an elementary school designed the activity of guessing the meaning of the two words "blind" and "deaf". He let one student guess the information provided by another student; however, this student failed to get the answer since there was no communication between the teacher and students. To avoid frustration like this, he immediately talked to students about the procedure of that activity, and after the negotiation, the manipulation of the class became clearer. The teacher then asked other students to give necessary help both in guessing and providing information of the words, which was proofed to be a success in reality.

\subsubsection{Negotiate the Evaluation of Students' Achievements}

The evaluation of students' achievements and development is also a most important step in the mechanism of negotiation. Traditionally, evaluation of student in China was made on the basis of the scores of examination. This is the well-known "examination-oriented education" and is greatly opposed by researchers and teachers. This kind of evaluation cares nothing of the progress or achievements learners made but the scores only. It is not hard to find that this kind of evaluation is unilateral and useless for promoting students' overall abilities. A new evaluation must be established if teaching is to be enhanced. Woodward (1993) once explains negotiated evaluation as a system of evaluation which helps those with a vested interest in the child's progress to make accurate decision about that child in order to better accommodate and stimulate his or her learning as well as to record and report the child's progress over time. Therefore, what we need in assessing the teaching and learning is the three-dimensional negotiated evaluation that combines the teacher, students, the peers and parents altogether as a unified ecological system.

Negotiated evaluation will no doubt provide a more scientific and reliable evaluation of students' progress or achievements. By negotiated evaluation, we mean that students could also have a say in deciding the evaluation of their progress. Teachers should thereby care about any possible factor that might relate to students' learning. They need to know the intricate driving power of student's learning. Only then can the teacher provide the scientific and balanced judgments that could help to encourage and promote students in the classroom. Besides, parents also should involve and communicate with the teacher and their children regularly because they may know more of students, especially when they are at home. These steps will involve all the three types of 
negotiation. Teachers must be aware that these types of negotiation are actually intermingled with each other and must be dealt with delicately.

\subsection{Choose the Suitable Ways of Negotiation}

\subsubsection{Make a Discussion between the Teacher and Students}

As one of the most important methods of negotiation, the discussion between the teacher and a collection of students needs the greatest attention in EFL teaching practice. It is the teacher's responsibility to sponsor the discussion with students of all aspects of teaching content, teaching style and teaching methods. That is to say, the teacher should make a full preparation for the teaching aims, difficulties, and teaching tasks and make it explicit to students; then the discussion should be carried out for any problem that might appear. In doing so, it is necessary to choose some time deliberately for discussion or dialogue, through which, the teacher and students could communicate with each other with high quality. However, it needs to be pointed out that Chinese students are somewhat silent or passive in the class and they are supposed to listen to the teacher, take notes and do the exercises in the traditional culture. Therefore, the teacher must understand the reality of the traditional culture and students' common affective features, and plays the role of initiator of negotiation which in turn will make students form their own initiatives of reflection, retrospection and communication eventually. However, by discussion or dialogue, it doesn't mean the one between the teacher and students only, but also the ones between students themselves and within the student oneself, too, about how to learn, what to learn, how to cooperate with each other in language learning. In addition, they should discuss their learning style, learning strategies and learning motivation, etc. and try to find the best way to solve the problems they might meet.

\subsubsection{Have an Interview with Students}

Interview is a useful way for the teacher to get some deep information of learning or teaching from individuals. Usually, the teacher should first have some concepts of interview before this activity. For instance, some open or semi-open questions should be made before hand: Questions like "what do you think of your learning situation?" "What do you expect to learn in the class?", "What do you expect the teacher to do to help you learn English?" can be asked in the interview. Students are encouraged to answer the questions with an open mind in depth. Different form discussion with many students, interview provides a more wide range for the individual to talk about many problems they face. The teacher can design interviews according to his or her personal observation of students' behavior and learning outcomes so as to get to know their ideas, their expectations, their developmental situation, etc. As a result, he or she could know what should do next and have the timely information of the teaching effectiveness and adjust the teaching plan in time.

\subsubsection{Use Questionnaires}

Questionnaire is one of the effective ways to have negotiation with students as there are students who are shy and feel reluctant to talk about their opinions and ideas with the teacher or even some peers directly. Questionnaires are useful in that some students in China are accustomed to listening to the teacher obediently and they will feel pressured to talk about their learning and problems when communicating with the teacher face to face. In some cases, the information may not be true because students might tell a lie in order to please the teacher who has the "power" over him or her. With such an understanding, it is necessary that some covering questions can be set in the questionnaire to get an overall map of students' learning situation. Because there are students of various levels of proficiency, EFL teachers must be professional in designing questionnaire that can be used for the very group of students so as to collect necessary information.

\subsubsection{Form Peer Interaction}

The introduction of peer support is also of significance in that it helps to know students' development in a more reliable way. Students should engage in the effective peer evaluation work since they can understand each other even more than the teacher in some places that might not be noticed by the teacher. But what should be remembered is that they must make the evaluation on the basis of objectivity. In this stage, EFL teachers are supposed to provide more guidance and assistance to students. Peer interaction can be different at different levels of cognition in the classroom. For example, college students will have more freedom and work more effectively whilst students in middle school or elementary school need more support from the teacher. Generally, to use peer support effectively, it is necessary to train students purposefully before they engage in such an activity. The teacher needs to talk to students and let them understand what they should do and how to do inside and outside classroom. In the meantime, certain supervision for them is needed to ensure the work is on the right course instead of merely a superficial form. 


\section{Conclusion}

Teaching English as a foreign language is a complicated and flexible process which makes negotiation between the teacher and students a necessity. Traditional models of EFL teaching in China ignored the nature of interactivity and remained superficial in various activities. As a result, decision making was too simple and in most cases teacher-centered. Language leaning is in an ecological environment which involves the teacher, students and requires interaction and negation between the teacher and students. The whole teaching process is in fact a process of negotiation and decision making. Therefore, the teacher should trust and help students engage in the decision making process so that the decisions of teaching and learning can become more scientific and the teaching process more optimized. In fact, when students are involved in negotiation of various types, they are also initiated to be responsible for their own learning. In an EFL classroom in Chinese context, an optimistic model of teaching is that both the teacher and students are involved deeply so that each party will play its role appropriately and efficiently. In order to make the teaching process much more transparent, effective and decision making more scientific as in a flipped classroom, it is critical and urgent to establish the negotiation mechanism in the classroom, which will be a new direction in current English language teaching practice.

\section{Acknowledgements}

This paper is supported by the grant of the Project of Education and Teaching Reform Research of Leshan Normal University (project number: JG2015-YB08) and The Cultivated Project of Leshan Normal University for the National-level Project (project number: C1421).

\section{References}

Charteris, J., \& Smardon, D. (2015). Teacher agency and dialogic feedback: Using classroom data for practitioner inquiry. Teaching and Teacher Education, 50, 114-123. http://dx.doi.org/10.1016/j.tate.2015.05.006

Cook-Sather, A. (2006). Sound, presence, and power: Exploring "student voice" in educational research and reform. Curriculum Inquiry, 36(4), 359-390. http://dx.doi.org/10.1111/j.1467-873X.2006.00363.x

Cook-Sather, A., \& Youens, B. (2007). Repositioning students in initial teacher preparation: A comparative case study of learning to teach for social justice in the United States and in England. Journal of Teacher Education, 58(1), 62-75. http://dx.doi.org/10.1177/0022487106296216

Gao, X. J. (2013). Cultivation of Junior Middle School Students' Communicative Ability with the New

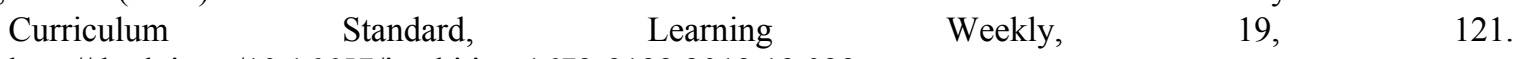
http://dx.doi.org/10.16657/j.cnki.issn1673-9132.2013.19.023

Isabel, S. (2002). Refining negotiation classroom work in a Spanish secondary school. In P. B. Michael, \& L. Andrew (Eds.), Classroom Decision-making (pp. 146-154). Shanghai: Shanghai Foreign Language Education Press.

Jack C. R., \& Charles, L. (2000). Reflective teaching in Second Language Classroom. Beijing: People's Education Press.

Long, M. H. (1981). Input, Interaction and second language acquisition. In H. Winitz, (Ed.), Native Language and foreign language acquisition (pp. 102-121). New York: New York Academy of Sciences. http://dx.doi.org/10.1111/j.1749-6632.1981.tb42014.x

Margaret, S. (2002). Negotiation of outcome: evaluation and revision decisions in the writing curriculum. In P. B Michael, \& L. Andrew (Eds.) Classroom Decision-making (pp. 64-74). Shanghai: Shanghai Foreign Language Education Press.

McCarthy, M. (1991). Negotiation in the Classroom, Journal of Further and Higher Education, 15(1), 75-79. http://dx.doi.org/10.1080/0309877910150108

Michael, P. B., \&Andrew, L. (2002). The Significance of Negotiation. In P. B. Michael, \& L. Andrew (Eds.), Classroom Decision-making (pp. 5-20). Shanghai: Shanghai Foreign Language Education Press.

Rowe, H. (1988). Metacognitive skills: promise and problems. Australian Journal of reading, 2(4), 227-236.

Stern, H. H. (1999). Fundamental Concepts of Language Teaching. Shanghai: Shanghai Foreign Language Education Press. http://dx.doi.org/10.2307/328070

Woodward, H. (1993). Negotiated evaluation. NSW: Primary English Teacher's Association.

Zhou, X. (2001). Humanism in Language Teaching. Foreign Languages and Their Teaching, 6, 34-36. 
http://dx.doi.org/ 10.13458/j.cnki.flatt.002362

Zhu, C. (2001). Psychology of Foreign Language Teaching. Shanghai: Shanghai Foreign Language Education Press.

\section{Copyrights}

Copyright for this article is retained by the author(s), with first publication rights granted to the journal.

This is an open-access article distributed under the terms and conditions of the Creative Commons Attribution license (http://creativecommons.org/licenses/by/4.0/). 